\title{
Instructional design in the development of an online course on Basic Life Support ${ }^{*}$
}

\author{
O design instrucional no desenvolvimento do curso on-line sobre Suporte Básico de Vida \\ El diseño instruccional en el desarrollo del curso en línea acerca del Soporte Básico de Vida
}

Lucia Tobase ${ }^{1}$, Heloisa Helena Ciqueto Peres ${ }^{2}$, Denise Maria de Almeida ${ }^{2}$, Edenir Aparecida Sartorelli Tomazini ${ }^{1}$, Meire Bruna Ramos ${ }^{3}$, Thatiane Facholi Polastri ${ }^{3}$

How to cite this article:

Tobase L, Peres HHC, Almeida DM, Tomazini EAS, Ramos MB, Polastri TF. Instructional design in the development of an online course on Basic Life Support. Rev Esc Enferm USP. 2017;51:e03288. DOI: http://dx.doi.org/10.1590/S1980-220X2016043303288

* Extracted from the thesis "Desenvolvimento e avaliação do curso on-line sobre Suporte Básico de Vida nas manobras de reanimação cardiopulmonar do adulto", Escola de Enfermagem, Universidade de São Paulo, 2016.

${ }^{1}$ Serviço de Atendimento Móvel de Urgências, São Paulo, SP, Brazil.

${ }^{2}$ Universidade de São Paulo, Escola de Enfermagem, Departamento de Orientação Profissional, São Paulo, SP, Brazil.

${ }^{3}$ Universidade de São Paulo, Faculdade de Medicina, Instituto do Coração, São Paulo, São Paulo, SP, Brazil.

\section{ABSTRACT}

Objective: To develop and evaluate an online course on Basic Life Support. Method: Technological production research of online course guided by the ADDIE (Analysis, Design, Development, Implementation, Evaluation) instructional design model based on Andragogy and the Meaningful Learning Theory. The online course was constructed in the platform Moodle, previously assessed by a group of experts, and then presented to the students of the Nursing School of the University of São Paulo, who assessed it at the end of the course. Results: The course was evaluated by the experts and obtained a mean score of 0.92 (SD 0.15), considered as good quality (between 0.90-0.94), and by the students, with a mean score of 0.95 (SD 0.03), considered as high quality (0.95-1.00). Conclusion: The instructional design used was found to be appropriate to the development of the online course. As an active educational strategy, it contributed to the learning on Basic Life Support during cardiac arrest-related procedures in adults. In view of the need for technological innovations in education and systematization of care in cardiopulmonary resuscitation, the online course allows the establishment of continuous improvement processes in the quality of resuscitation in the care provided by students and professionals.

\section{DESCRIPTORS}

Education, Nursing; Education, Distance; Educational Technology. Cardiopulmonary Resuscitation. 


\section{INTRODUCTION}

Following the evolution of education and technological innovations, the concept of Distance Learning (DL) is dynamically transformed, uniquely to the lived moment and the available technological resources. It is considered a technological communication system that replaces the face-to-face interaction that occurs in the classroom between teacher and student. It is a means of teaching that provides students with autonomous learning through the systematic, joint action of diverse didactic resources and support by the tutorial organization. According to Ordinance 4059/2004, Distance Education is compatible in graduation courses, making up to $20 \%$ of the total workload in disciplines offered in this modality ${ }^{(1)}$.

Expanding the scope and reach of education, Distance Education currently stands out as an alternative and differentiated modality. It has its own characteristics, language, and format, requiring an appropriate administration, design, monitoring, assessment, technology, as well as pedagogical resources to enhance the educational process ${ }^{(2)}$. This educational modality requires careful attention from its conception to its implementation, as well as monitoring of participants in the virtual environment. In this sense the instructional design as an educational project development and management model significantly influences the results to be achieved in the educational proposal, aiming to facilitate the learning process, starting from often known learning and instruction principles. It is related to the intentional action and systematic organization of the educational process, involving planning, development, and use of methods, techniques, didactic activities, and educational materials and products in a structured manner ${ }^{(3)}$.

Among the existing instructional design models, the systemic ones, such as the ADDIE Model (Analysis, Design, Development, Implementation, Evaluation), presents a broad scope, allowing an overview of the educational process and favoring decisions aimed at adjustments ${ }^{(3)}$. Regarding the stages: Analysis includes the identification of learning needs; the determination of activities; and the schedule. Design includes the listed objectives, learning activities, and selection of resources. Development presents the elaboration of the required materials, such as Learning Objects (LO), tutorials, texts, and animations. Implementation corresponds to the implementation and execution of the project. Evaluation corresponds to the verification of obtained results, potentialities, and improvement points in the project.

Within the area of Urgency and Emergency the Ministry of Health also aligns Distance Education in the public policies for emergency care, supporting trainings and qualification for professionals, including those working in the Mobile Emergency Medical Service (SAMU 192 - Serviço de Atendimento Móvel de Urgências) and the Care Units for Prehospital Emergencies ${ }^{(4)}$. The actions are in line with Ordinance 2048/2002, which highlights the importance and need of creating structures capable of problematizing the reality of the services in order to provide qualified care in emergency units ${ }^{(5)}$.
The American Heart Association (AHA/2015) guidelines also recommend the use of technology in the qualification and training of professionals. Short-term online courses are considered effective resources in the education and maintenance of learning related to resuscitation procedures ${ }^{(6)}$.

Among the teaching-related challenges in Emergencies, it is essential to expand the access to the teaching of Cardiopulmonar Resuscitation (CPR) procedures in order to provide early life support and minimize defibrillation time. The establishment of processes for the continuous improvement of resuscitation quality is critical, as cardiovascular diseases represent the main cause of cardiac $\operatorname{arrest}^{(7)}$. In cardiac arrest-related care, Basic Life Support (BLS) is considered the basis of resuscitation procedures, especially in out-of-hospital cardiac arrest, in which the most important determinant for survival is the presence of an individual capable of providing BLS in fundamental actions by promptly recognizing the condition, activating the emergency service, performing the $\mathrm{CPR}$, and using a defibrillator ${ }^{(8)}$.

Considering that BLS skills may be learned as easily by self-learning (video or computer) and by practice in comparison with traditional courses given by instructors ${ }^{(6)}$, a survey of research related to the theme was conducted prior to the proposition of this online course. It was verified that the teaching of BLS is often approached in a conventional way, relating theoretical and practical instructions in a face-to-face modality ${ }^{(9-10)}$.

Thus, with the objective of aligning technological resources in education on cardiopulmonary resuscitation procedures during cardiac arrest in adults, this study's goal was to develop and assess the online course on Basic Life Support guided by the ADDIE model as a methodological reference in the instructional design proposed for the development of face-to-face courses as well as in Virtual Learning Environments (VLEs).

\section{METHOD}

This was a descriptive study of technological production on the development and assessment of an online course on Basic Life Support offered to students from the first to the fourth year of the Bachelor's degree in Nursing of a public university in the city of São Paulo between November 2014 and February 2015. In addition to the research presentation and invitations made in the classroom, emails were sent to the students.

In the development of the online course, according to the $\mathrm{ADDIE}{ }^{(3)}$ model, the actions in the stages were:

Analysis: analysis of target-audience, local needs, and available resources. The theme approached included: characteristics of the course, self-instructional type; the workload allocated to the study on BLS in the Bachelor's degree course; the possibilities of expansion of the approach to the theme in the virtual environment as a complementary resource to the discipline content; applicability in theoretical activities in the classroom and in practical activities in the nursing laboratory. 
Design: selection of content, definition of instructional matrix, and elaboration of storyboard. Andragogic assumptions of adult education and the theory of meaningful learning were used due to the profile of adult students. AHA guidelines and guidelines of the Brazilian Society of Cardiology were used in the instructional matrix.

Development: creation of $\mathrm{LO}$ as a virtual class, interactive exercises, two videos about BLS procedures in CPR during cardiac arrest in adults, and the use of an Automatic External Defibrillator (AED), with an infographic on the BLS stages. Partnerships enabled the creation of LO with the resources of the Virtual $\mathrm{Man}^{(11)}$ in the area of Telemedicine of the Medical School of the Universidade of São Paulo.

Implementation: decision for the virtual environment to access the produced material. The course was implemented in the platform Moodle ${ }^{\circledR}$ (Modular Object Oriented Distance Learning). This is a free, open software to support learning and teaching processes that may be used, modified, and redistributed without any restrictions. It is available in the university to host virtual disciplines and extension courses. Participants were provided with a login and a password to access it. During the course, with a workload of 20 hours, the students were followed up in the VLE between November 2014 and February 2015 by eight mentors consisting of nurses with specializations in the areas of higher education in nursing, emergency, and distance learning.

Evaluation: evaluation of the educational process, participants, and results obtained in the course. Prior to making the online course available to the students, it was evaluated by a group of experts consisting of 12 nurses with experience in higher education in nursing, emergency, and distance education.

Based on an analysis of the Learning Object Quality Evaluation Instrument from the perspective of the user, version 5.0, proposed by the Central Coordination for Distance Education - Pontifícia Universidade Católica - PUC-Rio ${ }^{(12)}$ with 70 items, this study used 20 items related to software assessment, plus seven items for the identification of the professional profile. The instrument was structured in an electronic form and submitted to the experts, whose suggestions favored later adjustments.

A pre-test and post-test with 20 questions was applied in the VLE before and at the end of the study with orientation for resolution in a single attempt in order to evaluate the theoretical learning of the students.

A checklist was used to assess the practical learning in simulation. At the end the students assessed the course with a printed instrument, applied in person, based on the Learning Object Quality Evaluation Instrument from the perspective of the student proposed by the Central Coordination for Distance Education (CCEAD - Coordenação Central de Educação a Distância) - Pontifícia Universidade Católica - PUC-Rio ${ }^{(13)}$.

Thirteen items were added to the 25 original items to identify the profile of the student, assessment of satisfaction, contributions for learning, and suggestions to improve the online course. In the instruments proposed by CCEAD the value of each indicator varies between $0-0.25-0.5-0.75-$ $1-\mathrm{N} / \mathrm{A}$, with 0 (zero) representing the most negative and 1 representing the most positive; N/A indicates that the item does not apply. The total value of the measurement considers that $0.95-1.00$ corresponds to high quality; $0.90-0.94$ to good quality; $0.60-0.89$ to medium quality; $0.00-0.59$ to the absence of quality.

The software Statistical Package for the Social Sciences ${ }^{\circledast}$ (SPSS), version 22 was used in the statistical analysis. Mean values and standard deviations were calculated for course evaluation scores and absolute and relative frequencies for gender, age, and motivation for participation in the course.

The research was approved by the Research Ethics Committee under consolidated opinion 526.932 and identifier CAAE 27029214.4.0000.5392.

\section{RESULTS}

The online BLS course was allocated in the area dedicated to Extension Courses at http://cursosextensao.usp. br/course/view.php?id=133. Its initial screen had prominent presentation in relation to the approached theme and a welcoming text for reception of the students. It was organized into five units, consisting of Environmental Adaptation, Pre-test, Interactive Class, Support Material with Media Library, and Post-test. Environmental adaptation contained a Navigation Route to guide the use of the online environment and a Learning Route for knowledge on the available contents and stages to be taken during the course. In Getting to Know the Course, there was information about workload, objectives, methodology, evaluation and certification, a tutorial to guide the navigation of the participant in the VLE, functions of buttons and icons, use of the Menu, and a Glossary.

Two forums were made available for asynchronous interaction between participants and mentors. The Personal Presentation forum allowed the initial socialization and integration between the participants in the virtual environment, while Participant Support provided clarification of doubts and guidance on the assessment activity. The instructors monitored the students in both forums, but the self-instructional learning characteristics of the course in a self-managed manner did not require frequent intervention by the instructors.

After the pre-test in the VLE the navigation was free to attend the Interactive Class, watch videos about BLS and AED, participate in interactive exercises, access the Infographic, the media library, and the library. In-person assessment in practical simulation was scheduled at the end, after the Post-test in the VLE.

The difference in the scores between the pre- and post-test was considered as a parameter to assess the theoretical learning in the learning results analysis. Paired $\mathrm{t}$-test indicated a significant increase in learning: pre-test $(6.4 \pm 1.61)$; post-test $(9.3 \pm 0.82) ; \mathrm{p}<0.001$; and mean practical evaluation $(9.1 \pm 0.95)$. In relation to the assessment of the course, the online course was assessed by 12 expert nurses (mean age of 42.25 years, mean time of professional training of 17.33 years, time of professional 
performance over 10 years, qualifications corresponding to three (25\%) specializations, seven (58.3\%) MSc and two (16.6\%) PhD), prior to making it available to the students. They worked in different areas, such as continuing education instructors, mobile emergency care public service, hospital service continuing education specialized in cardiology, pedagogical consultancy in the area of Nursing, educators with training in instructional design, educators of higher education in Nursing, in family health strategy, and in distance education coordination.

The course was evaluated with a mean score of 0.92 (SD 0.15), corresponding to good quality (between 0.90-0.94) according to the parameters established in the instrument used, as shown in Table 1.

Table 1 - Assessment of the online course in the perspective of experts - São Paulo, SP, Brazil, 2014-2015.

\begin{tabular}{lccc}
\hline Aspects & Mean & SD & Quality \\
\hline Easy navigation & 0.85 & 0.25 & Median \\
Clear information & 0.94 & 0.16 & Good \\
Easiness to locate information & 0.85 & 0.20 & Median \\
Relevance & 0.96 & 0.10 & High \\
Contextualization & 0.88 & 0.17 & Median \\
Content correction & 0.98 & 0.08 & High \\
Multiple windows & 0.89 & 0.17 & Median \\
Easiness of learning in interaction & 0.96 & 0.10 & High \\
Efficiency of use & 0.98 & 0.07 & High \\
Easiness of return & 0.81 & 0.24 & Median \\
Ergonomics & 0.96 & 0.10 & High \\
Aesthetics & 0.94 & 0.16 & Good \\
Use of special marks & 0.96 & 0.10 & High \\
Use of audiovisual resources & 0.94 & 0.16 & Good \\
References & 0.98 & 0.07 & High \\
Interactivity & 0.81 & 0.22 & Median \\
Error management & 0.92 & 0.13 & Good \\
User support & 0.96 & 0.10 & High \\
Information quality & 0.96 & 0.10 & High \\
Portability & 1.00 & 0.00 & High \\
\hline
\end{tabular}

Regarding the profile of the students, of the 62 (100\%) graduates of the course, $87 \%$ were female, with a mean age of 21.47 years (SD 2.39); $90.3 \%$ were in the first and second years, and $9.7 \%$ were in the third and fourth years. In relation to previous knowledge, 50\% had not participated in emergency courses prior to the online course; 53.3\% did not know about BLS; $61.2 \%$ knew the platform Moodle ; and $69.1 \%$ had not previously participated in Distance Education courses. In relation to digital fluency, $100 \%$ had access to the Internet, most of them (98.9\%) via mobile phones. Regarding the motivation to take the course, $96.8 \%$ mentioned the practical applicability of the learning. From the perspective of the students, the course was assessed with a mean score of 0.95 (SD 0.03), corresponding to high quality $(0.95-1.00)$ according to the parameters established in the instrument used, as shown in Table 2.
Table 2 - Assessment of the online course in the perspective of students - São Paulo, SP, Brazil, 2014-2015.

\begin{tabular}{|c|c|c|c|c|}
\hline Aspects & $\mathbf{n}$ & Mean & SD & Quality \\
\hline Clear content & 62 & 0.99 & 0.04 & High \\
\hline $\begin{array}{l}\text { Resources are motivating } \\
\text { factors }\end{array}$ & 62 & 0.95 & 0.11 & High \\
\hline Vocabulary is appropriate & 62 & 0.97 & 0.08 & High \\
\hline $\begin{array}{l}\text { Amount of information is } \\
\text { appropriate }\end{array}$ & 62 & 0.97 & 0.08 & High \\
\hline $\begin{array}{l}\text { Memorization of information is } \\
\text { facilitated }\end{array}$ & 62 & 0.95 & 0.10 & High \\
\hline $\begin{array}{l}\text { Presents immediate feedback } \\
\text { and clarity of language }\end{array}$ & 61 & 0.95 & 0.10 & High \\
\hline $\begin{array}{l}\text { Harmony between } \\
\text { colors, fonts, and animations }\end{array}$ & 61 & 0.96 & 0.09 & High \\
\hline Appropriate soundtrack/audio & 57 & 0.95 & 0.10 & High \\
\hline $\begin{array}{l}\text { Organized and sequenced } \\
\text { contents }\end{array}$ & 62 & 0.96 & 0.09 & High \\
\hline Appropriate language & 62 & 0.98 & 0.06 & High \\
\hline $\begin{array}{l}\text { Contextualized and coherent } \\
\text { content }\end{array}$ & 62 & 0.99 & 0.04 & High \\
\hline $\begin{array}{l}\text { Themes of different disciplines } \\
\text { are approached }\end{array}$ & 59 & 0.90 & 0.12 & Good \\
\hline Refers to everyday life & 61 & 0.97 & 0.09 & High \\
\hline $\begin{array}{l}\text { Presentation in a playful, } \\
\text { challenging and clear manner }\end{array}$ & 62 & 0.96 & 0.09 & High \\
\hline Language stimulates interest & 62 & 0.96 & 0.09 & High \\
\hline $\begin{array}{l}\text { Combines aesthetics with } \\
\text { content }\end{array}$ & 60 & 0.91 & 0.13 & Good \\
\hline $\begin{array}{l}\text { Makes use of examples and } \\
\text { analogies }\end{array}$ & 61 & 0.91 & 0.13 & Good \\
\hline Allows easy navigation & 62 & 0.97 & 0.08 & High \\
\hline $\begin{array}{l}\text { Information is easy to find, } \\
\text { with routes and menu }\end{array}$ & 62 & 0.94 & 0.11 & Good \\
\hline $\begin{array}{l}\text { Content is presented in a } \\
\text { logical manner }\end{array}$ & 62 & 0.98 & 0.06 & High \\
\hline $\begin{array}{l}\text { Interaction and navigation are } \\
\text { easy to understand }\end{array}$ & 62 & 0.94 & 0.12 & Good \\
\hline Navigation is simple & 62 & 0.92 & 0.13 & Good \\
\hline Easiness of return & 62 & 0.94 & 0.11 & Good \\
\hline $\begin{array}{l}\text { Allows interaction of the } \\
\text { student with the content }\end{array}$ & 62 & 0.96 & 0.10 & High \\
\hline Displays error messages & 26 & 0.88 & 0.18 & Median \\
\hline Presents support mechanisms & 52 & 0.92 & 0.12 & Good \\
\hline $\begin{array}{l}\text { Provided confidence to } \\
\text { perform the BLS }\end{array}$ & 52 & 0.86 & 0.18 & Median \\
\hline $\begin{array}{l}\text { Depth of content expanded } \\
\text { knowledge }\end{array}$ & 62 & 0.92 & 0.17 & Good \\
\hline $\begin{array}{l}\text { Consistency between } \\
\text { objectives, contents and tools }\end{array}$ & 62 & 0.98 & 0.06 & High \\
\hline $\begin{array}{l}\text { The strategies used were } \\
\text { effective for learning }\end{array}$ & 62 & 0.97 & 0.08 & High \\
\hline $\begin{array}{l}\text { The course favored autonomy } \\
\text { and search for knowledge }\end{array}$ & 62 & 0.96 & 0.09 & High \\
\hline Workload was sufficient & 61 & 0.93 & 0.14 & Good \\
\hline $\begin{array}{l}\text { Tutoring has contributed to } \\
\text { learning }\end{array}$ & 61 & 0.96 & 0.09 & High \\
\hline
\end{tabular}

When questioned after completing the online course whether they felt able to perform the BLS procedures, most (58, 93.5\%) of the students replied affirmatively, two (3.2\%) were in doubt regarding this ability, and two (3.2\%) replied negatively.

The students, identified at the end of the speeches, expressed that they felt confident to apply the BLS, emphasizing the following aspects: 
I was able to understand all the theory; the course provided me with theoretical and practical knowledge, comprehensively covering the BLS and thus making me confident to perform the procedures (S60).

The course was very explanatory and didactic; it used not only written materials, but also videos, which provided me with more confidence (S58).

This course provided instruments, such as in the practical part, in which it was clearly shown that I am able to help. By knowing the techniques I know I will be able to help in any occurrences that may occur when I am around, if someone needs help (S56).

The students that were in doubt or did not feel able to apply the BLS expressed:

I feel confident, but not fully; I need to practice more (S32).

I believe I still need more training (S34).

Istill do not feel confident, despite the good quality of the course (S9).

I do not feel able; learning in theory is different from the practice (S21).

When questioned about their impressions of the course, the reactions of the students were $100 \%$ positive, highlighting the following aspects:

In addition to an enlightening content, the online course provides comfort and convenience in relation to when and where to study (S29).

It was a very enlightening, didactic course, with good material for the theoretical classes and a very well-organized, taught, conducted, and supported practical activity (S30).

I want to congratulate the elaboration of the course; everyone should have the chance to take it and acquire this knowledge (S56).

When questioned about the applicability of the acquired knowledge, $100 \%$ of the students associated the importance of the course with the training of professionals and citizens, mentioning:

The course is very important to the training of health professionals, and the way it is presented adds a lot (S30).

The course is great, dynamic, and it should be considered a mandatory course ( $\mathrm{S} 60)$.

I believe that this modality of course could be offered to the population as a whole, as it allows an easy understanding and has great practical use (S58).

In the assessment of the online course, when questioned whether or not they would recommend the course, 100\% replied affirmatively. Moreover, they emphasized that the learning is useful for all, students and professionals.

Recommendations of the students regarding the course include:

I learned a lot in the course and I was able to take it in a fast and effective way; I recommended it to my friends (S53).

I recommend the course because it provides both theoretical and practical knowledge. In addition it refers to situations that we may possibly have to deal with in our personal and professional life (S2).
When questioned about the adequacy in relation to the course structure, $100 \%$ replied positively. It was found that the selection of content, resources, and activities was appropriate and favored learning, emphasizing the following:

The summary of the cardiovascular system, the content of the $B L S$ were introduced in a dynamic and didactic way. Doubts were clarified (S57).

The course explains and demonstrates the whole procedure step-by-step; it was possible to resume a given subject as many times as necessary, until we felt confident on the subject (S53).

\section{DISCUSSION}

Learning life support procedures is highly relevant. According to the AHA, the training and qualification for a responsive assistance significantly affect the success of resuscitation and increase the chance of survival after a cardiac arrest episode ${ }^{(14)}$. Studies on the theme contribute to the understanding of the teaching-learning process, the adequacy of the strategies in the construction of knowledge, and the practical application of the BLS in CPR procedures, thus expanding the scope of educational resources and courses, including in Distance Education ${ }^{(15)}$.

The online BLS course proposed in the present study enabled unlimited access to the content, with flexibility in relation to individual pace according to the availability of time and choice of the most appropriate place to study. Educational projects about life support procedures require a careful outline in the instructional design, supported by adult-centered learning theories and models aimed at learning in the cognitive, psychomotor, and behavioral fields ${ }^{(14)}$. The ADDIE model was found to be appropriate in the instructional design of the online course. No studies were found with this design on BLS, but similar research on pain $^{(16)}$ and interactive educational technology ${ }^{(17)}$ indicated that the model was relevant, allowing the organization of the disciplines, courses, modules or lessons, as well as being useful for both inexperienced and experienced professionals ${ }^{(3)}$.

The logical and coherent choice of instructional design model based on the experienced reality supports the practical use and generates user satisfaction and effectiveness in the teaching-learning process. In the construction of the online course, each stage of the instructional design includes several activities and results that support the following stages in an integrated way. The complexity of each stage depends on the problems to be faced and the required level of qualification $^{(18)}$.

The analysis of the contribution of the research in the scenario of the study considered that in the syllabus of the bachelor's degree the content on BLS in adults is taught in the third year in the discipline Nursing in Health in Adult and Elderly under Critical Care with a workload of 405 hours. Two hours are allocated for a theoretical approach to Basic Life Support and Advanced Life Support in Cardiology. For practice, two hours are allocated to BLS and two hours to advanced support.

In addition to these moments of study, the possibility of the contribution of the online BLS course to the integration 
of knowledge in the classroom and in distance learning was considered in a moment in which the discipline is offered, as well as in other interdisciplinary approaches. This strategy is in line with the results of investigations and guidelines for resuscitation that converge to the use of videos and online courses as a resource in education on life support ${ }^{(19)}$.

The construction of the online BLS course had the aim of stimulating the autonomy of the participants, favoring the self-managed learning process in a self-instructional manner, combining the assumptions of Andragogy and Meaningful Learning Theory with the educational technologies based on the profile of the students seeking distance education courses. Most are adults, presenting previous experiences that may be widely used. In general this population feels more motivated to deepen their knowledge when there is practical application of the learning, making the learning more meaningful, with a higher chance of learning retention ${ }^{(20)}$.

In the teaching-learning process on cardiopulmonary resuscitation there is no difference in the learning results between conventional, classroom-based, instructor-led courses and self-instruction via video in terms of increased theoretical and practical learning, with consequent improved performance. Therefore, computer-based studies associated with the practice of resuscitation procedures may represent a reasonable alternative to the benefits of a higher level of standardization, in addition to the potential reduction in the time and resources required for learning ${ }^{(14)}$. In addition, the VLE allows access to knowledge, where students may access the material and study in the desired and required frequency, according to their individual pace and availability, providing easy access in different locations, through different gadgets, including mobile devices.

This frequent and early approximation with the theme is highly relevant, as it contributes to the retention of the learned life support procedures, taking into account that knowledge tends to degrade over time. Short, frequent trainings are highly recommended; the greater the exposure to the content, the greater the retention and confidence in the application of life support ${ }^{(21)}$. Although theoretical learning reaches satisfactory levels at the end of the course or training, a concern regarding learning retention was found in relation to the life support performance skills during the time elapsed after the educational intervention, ranging between $50 \%$ and $60 \%$ in general $^{(22)}$.
In order to stimulate learning, the search for knowledge, and updates from the training to the professional practice, the emphasis on active strategies and practical activities offered more frequently and with higher periodicity aims at dissolving deficiencies in the training of students and in permanent education of health professionals. Such a search favors learning retention and avoids the deterioration of abilities that tend to decline over time ${ }^{(23)}$; thus the performance becomes confident and safe when providing BLS ${ }^{(24-25)}$.

Among the reports, most students considered themselves as able to perform the BLS procedures in the event of cardiac arrest situation after completing the online course. The results of the analyses of theoretical learning, practical activities, and narratives about the confidence of most students allow the inference that, in general, the online course provided resources so that they felt prepared to provide the BLS. Understanding motivation as an important element in the teaching-learning process in the dimension related to energetic load exerted in the act of getting to know is part of the pedagogical common sense. In the construction of knowledge to respond positively or negatively to the needs, interests, affection, desires, ideologies, and senses, motivation contributes to a meaningful learning as the individual needs to want, to feel the need to learn ${ }^{(26)}$.

\section{CONCLUSION}

The online Basic Life Support course favored learning, was assessed as good and high quality by experts and students, and the ADDIE model was considered appropriate to the design of the course. As an environment promoting knowledge and reflection on emergency actions, it stimulates the clinical reasoning and decision making of the participants, favoring meaningful learning about resuscitation procedures. It allows the expansion of access to the teaching of cardiopulmonary resuscitation procedures within the scope of permanent education in view of the need to establish processes for the continuous improvement of quality of cardiopulmonary resuscitation. Other researches may be conducted to assess the learning of professionals in a virtual environment regarding resuscitation procedures in relation to time and frequency of exposure to the theoretical contents and practical activities for a better level of retention in relation to potentialities and fragilities in the distance education process and management of technology during learning.

\section{RESUMO}

Objetivo: Desenvolver e avaliar o curso on-line sobre Suporte Básico de Vida. Método: Pesquisa de produção tecnológica de curso on-line, orientada pelo modelo de design instrucional ADDIE (Analysis, Design, Development, Implementation, Evaluation), fundamentada na Andragogia e na Teoria da Aprendizagem Significativa. O modelo foi construído na plataforma Moodle, avaliado previamente por um grupo de especialistas, e então apresentado aos estudantes na Escola de Enfermagem da Universidade de São Paulo, sendo avaliado por estes ao término do curso. Resultados: O curso foi avaliado pelos especialistas e obteve média 0,92 (DP 0,15), considerado de boa qualidade (entre 0,90-0,94), e pelos estudantes, com média 0,95 (DP 0,03), considerado de alta qualidade $(0,95-1,00)$. Conclusão: $\mathrm{O}$ design instrucional utilizado mostrou-se adequado ao desenvolvimento do curso on-line. Como estratégia educacional ativa, contribuiu para o aprendizado sobre Suporte Básico de Vida, durante as manobras na parada cardiorrespiratória do adulto. Frente à necessidade de inovações tecnológicas no ensino e de sistematização do atendimento na reanimação cardiopulmonar, o curso on-line permite estabelecer processos de melhoria contínua da qualidade de reanimação, em atendimentos prestados por estudantes e profissionais.

\section{DESCRITORES}

Educação em Enfermagem; Educação a Distância; Tecnologia Educacional; Reanimação Cardiopulmonar. 


\section{RESUMEN}

Objetivo: Desarrollar y evaluar el curso en línea acerca del Soporte Básico de Vida. Método: Investigación de producción tecnológica de curso en línea, orientada por el modelo de diseño instruccional ADDIE (Analysis, Design, Development, Implementation, Evaluation), fundamentada en la Andragogía y la Teoría del Aprendizaje Significativo. El modelo fue construido en la plataforma Moodle, evaluado previamente por un grupo de especialistas, y luego presentado a los estudiantes en la Escuela de Enfermería de la Universidad de São Paulo, siendo evaluado por estos al término del curso. Resultados: El curso fue evaluado por los expertos y obtuvo promedio 0,92 (DE 0,15), considerado de buena calidad (entre 0,90-0,94), y por los estudiantes, con promedio 0,95 (DE 0,03), considerado de alta calidad (0,95-1,00). Conclusión: El diseño instruccional utilizado se mostró adecuado al desarrollo del curso en línea. Como estrategia educativa activa, contribuyó al aprendizaje acerca del Soporte Básico de Vida, durante las maniobras en el paro cardiorrespiratorio del adulto. Frente a la necesidad de innovaciones tecnológicas en la enseñanza y de sistematización de la atención en la reanimación cardiopulmonar, el curso en línea permite establecer procesos de mejora continua de la calidad de reanimación en atenciones prestadas por estudiantes y profesionales.

\section{DESCRIPTORES}

Educación en Enfermería; Educación a Distancia; Tecnología Educacional; Reanimación Cardiopulmonar.

\section{REFERENCES}

1. Brasil. Ministério da Educação. Portaria n. 4.059, de 10 de dezembro de 2004. Regulamenta a modalidade semipresencial e da carga horária para modalidade à distância no Ensino Superior [Internet]. Brasília; 2004 [citado 2016 out. 3]. Disponível em: http://portal.mec.gov.br/sesu/arquivos/pdf/nova/acs_portaria4059.pdf

2. Brasil. Ministério da Educação; Secretaria de Educação a Distância. Referenciais de qualidade para cursos de educação à distância [Internet]. Brasília; 2007 [citado 2016 out. 3]. Disponível em: http://portal.mec.gov.br/seed/arquivos/pdf/legislacao/refead1.pdf

3. Ono T. The construction of an instructional design model for Medical English Education in Japan [Internet]. 2014 [cited 2016 July 29]. Available from: http://web.icu.ac.jp/iers/files/2014/08/es_54_ono.pdf

4. Hospital Alemão Oswaldo Cruz; Brasil. Ministério da Saúde, Sistema Único de Saúde. Capacitação dos Profissionais de Atendimento Pré-Hospitalar Móvel (SAMU 192) e APH Fixo [Internet]. São Paulo; 2016 [citado 2016 jul. 8]. Disponível em: http://www.capacitacaosamuhaoc.com.br/samu/login/arquivos/apostila_SAMU_v4.pdf

5. Brasil. Ministério da Saúde. Portaria $n^{\circ}$ 2048, de 5 de novembro de 2002. Aprova o Regulamento Técnico dos Sistemas Estaduais de Urgência e Emergência [Internet]. Brasília; 2002 [citado 2016 jul. 8]. Disponível em: http://bvsms.saude.gov.br/bvs/saudelegis/gm/2002/ prt2048_05_11_2002.html

6. American Heart Association. Destaques da American Heart Association 2015. Atualização das diretrizes de RCP e ACE. Versão em português [Internet]. Dalas: AHA; 2015 [citado 2016 ago. 15]. Disponível em: https://eccguidelines.heart.org/wp-content/uploads/2015/10/2015AHA-Guidelines-Highlights-Portuguese.pdf

7. Gonzalez MM, Timerman S, Oliveira RG, Polastri TF, Canesin MF, Schimidt A et al. I Diretriz de Ressuscitação Cardiopulmonar e Cuidados Cardiovasculares de Emergência da Sociedade Brasileira de Cardiologia. Arq Bras Cardiol [Internet]. 2013 [citado 2016 out. 25]. Disponível em: http://www.scielo.br/pdf/abc/v101n2s3/v101n2s3.pdf

8. Berg RA, Hemphill R, Abella BS, Aufderheide TP, Cave DM, Hazinski MF, et al. Part 5: Adult Basic Life Support. 2010 American Heart Association guidelines for cardiopulmonary ressuscitation and emergency cardiovascular care. Circulation. 2010;122(18 Suppl 3):S685-705.

9. Bellan MC, Araújo IIM, Araújo S. Capacitação teórica do enfermeiro para o atendimento da parada cardiorrespiratória. Rev Bras Enferm [Internet]. 2010 [citado 2016 nov. 09]; 63(6):1019-27. Disponível em: http://www.scielo.br/pdf/reben/v63n6/23.pdf

10. Boaventura AP, Miyadahira AMK. Programa de capacitação em ressuscitação cardiorrespiratória com uso do desfibrilador externo automático em uma universidade. Rev Gaúcha Enferm. 2012;33(1):191-4. DOI: http://dx.doi.org/10.1590/S1983-14472012000100025

11. Wen CL. Teleducação em saúde. In: Prado C, Peres HHC, Leite MMJ, organizadoras. Tecnologia da informação e da comunicação em enfermagem. São Paulo: Atheneu; 2011. p. 127-37.

12. Campos GHB, Martins I, Nunes BP. Instrumento para a Avaliação da Qualidade de Objetos de Aprendizagem: perspectiva do usuário [Internet]. Rio de Janeiro: PUC; 2008 [citado 2016 ago. 2]. Disponível em: http://web.ccead.puc-rio.br/condigital/portal/InstrAvaliacao.pdf

13. Campos GHB, Martins I, Nunes BP, Roque GOB. Instrumento para a Avaliação da Qualidade de Objetos de Aprendizagem: perspectiva do aluno [Internet]. Rio de Janeiro: PUC; 2008 [citado 2017 mar. 29]. Disponível em: http://web.ccead.puc-rio.br/condigital/portal/ Instrumento_Condigital_Aluno.pdf

14. Bhanji F, Donoghue AJ, Wolff MS, Flores GE, Halamek LP, Berman JM, et al. Part 14: Education: 2015 American Heart Association Guidelines Update for Cardiopulmonary Resuscitation and Emergency Cardiovascular Care. Circulation. 2015;132(18 Suppl 2):S561-73.

15. Andrade JP, Mattos LAP, Carvalho AC, Machado CA, Oliveira GMM. Programa de qualificação de médicos na prevenção e atenção integral às doenças cardiovasculares. Arq Bras Cardiol [Internet]. 2013 [citado 2015 jun. 29];100(3):203-11. Disponível em http://www.arquivosonline.com.br/2013/10003/pdf/interativa-10003.pdf

16. Alvarez AG, Dal Sasso GTM. Virtual learning object for the simulated evaluation of acute pain in nursing students. Rev Latino Am Enfermagem [Internet]. 2011 [cited 2015 June 29]; 19(2):229-37. Available from: http://www.scielo.br/pdf/rlae/v19n2/02.pdf

17. Landeiro MJS, Peres HHC, Martins TV. Construction and evaluation of interactive educational technology for family members acting as caregivers on caring for dependent people. Rev Eletr Enf [Internet]. 2017 [cited 2017 Aug 07];19:a13. Disponível em: http://dx.doi.org/10.5216/ree.v19.38115

18. Escola Nacional de Administração Pública. Desenho de Cursos: introdução ao modelo ADDIE [Internet]. Rio de Janeiro: ENAP; 2015 [citado 2016 out. 2]. Disponível em: http://repositorio.enap.gov.br/bitstream/1/2289/1/Introdu\%C3\%A7\%C3\%A3o\%20ao\%20modelo\%20 ADDIE_M\%C3\%B3dulo\%201-alterado.pdf 
19. Bowden T, Rowlands A, Buckwell M, Abbot S. Web-based video and feedback in the teaching of cardiopulmonary resuscitation. Nurse Educ Today. 2012;32(4):443-7.

20. Leigh K, Whitted K, Hamilton B. Integration of andragogy into preceptorship. J Adult Educ. 2015;44(1):9-17.

21. Ruijter PA, Biersteker H, Biert J, Van Goor H, Tan E. Retention of first aid and basic life support skills in undergraduate medical students. Med Educ Online [Internet]. 2014 [cited 2016 Nov 09];19:24841. Available from: https://www.ncbi.nlm.nih.gov/pmc/articles/PMC4224704/

22. Giotakis E, Chalkias A, Castren M, Karlis G, Tarantinos K, lacovidou N, et al. Pre-test-based group forming in Advanced Cardiac Life Support courses increases acquisition and retention of resuscitation knowledge. Am J Emerg Med. 2014;32(5):478-9.

23. Oermann MH, Kardong-Edgren SE, Odom-Maryon T. Effects of monthly practice on nursing students'CPR psychomotor skill performance. Resuscitation. 2011;82(4):447-53.

24. Ferreira JVB, Ferreira SMB, Casseb GB. Perfil e Conhecimento Teórico de Médicos e Enfermeiros em Parada Cardiorrespiratória, município de Rio Branco, AC. Rev Bras Cardiol [Internet]. 2012 [citado 2016 out. 29];25(6):464-70. Disponível em: http://www.rbconline.org.br/ wp-content/uploads/v25n06a03.pdf

25. Alves CA, Barbosa CNS, Faria HTG. Parada cardiorrespiratória e enfermagem: o conhecimento acerca do suporte básico de vida. Cogitare Enferm [Internet]. 2013 [citado 2016 jun 29];18(2):296-301. Disponível em: http://ojs.c3sl.ufpr.br/ojs/index.php/cogitare/article/viewFile/32579/20693

26. Prado C, Pereira IM, Fugulin FMT, Peres HHC, CastilhoV. Seminars in dialectical perspective: experience in the nursing administration discipline. Acta Paul Enferm [Internet]. 2011 [cited 2017 July 20];24(4):582-5. Available from: http://www.scielo.br/pdf/ape/v24n4/en_a21v24n4.pdf 